\title{
Proteomics of a toxic dinoflagellate Alexandrium catenella DH01: Detection and identification of cell surface proteins using fluorescent labeling
}

\author{
LI Cheng, WANG DaZhi", DONG HongPo, XIE ZhangXian \& HONG HuaSheng \\ State Key Laboratory of Marine Environmental Science, College of the Environment and Ecology, Xiamen University, Xiamen 361005, China
}

Received November 3, 2011; accepted March 19, 2012; published online May 4, 2012

\begin{abstract}
Alexandrium catenella DH01 is a toxic dinoflagellate species that is able to not only produce paralytic shellfish toxins, but also cause harmful algal blooms along the coast of China. In this study, we presented a new protocol for specific labeling and detection of the cell surface proteins (CSPs) of A. catenella DH01 cells using CyDye difference gel electrophoresis (DIGE) fluor minimal dyes. CSPs were identified using two-dimensional gel electrophoresis (2-DE) and MALDI TOF-TOF mass spectrometry (MS). The results showed that the fluorescent cyanine dye Cy3 could specifically label the CSPs of A. catenella DH01, with minimal labeling of intracellular proteins. Among three protein extraction methods evaluated, the Trizol method was the most efficient to extract CSPs with respect to protein spot number and resolution. Forty-one CSPs were separated and identified from A. catenella DH01 by 2-DE, in which 14 were identified in the protein database using MALDI TOF-TOF MS analysis. This work represents the first attempt to investigate the CSPs of A. catenella using the CyDye DIGE fluor dyeing method that provides a potentially important tool for future comprehensive characterization of CSPs and elucidation of the physiological functions of CSPs in dinoflagellates.
\end{abstract}

Alexandrium catenella, cell surface protein, cyanine dye, protein extraction, two-dimensional gel electrophoresis, MALDI TOF-TOF

Citation: $\quad$ Li C, Wang D Z, Dong H P, et al. Proteomics of a toxic dinoflagellate Alexandrium catenella DH01: Detection and identification of cell surface proteins using fluorescent labeling. Chin Sci Bull, 2012, 57: 3320-3327, doi: 10.1007/s11434-012-5156-5

Alexandrium is a dinoflagellate genus that is widely spread throughout many regions of the world [1,2]. Many species within this genus are able to produce paralytic shellfish toxins (PSTs), a family of potent neurotoxins, which specifically bind to sodium channels in neural cells and result in paralytic shellfish poisoning [3]. In the past few decades, harmful algal blooms (HABs) formed by Alexandrium have been significantly increasing in frequency, intensity and distribution, resulting in serious economic and public health related problems, which has attracted significant attention to this genus from various aspects [4].

A free-living Alexandrium cell is covered by theca or amphiesma consisting of a continuous outermost membrane, an outer plate membrane and a single-membrane bound

*Corresponding author (email: dzwang@xmu.edu.cn) thecal vesicle [5]. Inside this vesicle, a number of cellulosic thecal plates are subtended by a pellicular layer. Thecal plates usually consist primarily of cellulose and polysaccharides, with a small amount of protein [6,7]. Previous studies of Alexandrium cell walls have been mainly based on electron microscopic and cytochemical observations [8], and molecular information on cell wall biogenesis and dynamics is lacking. For example, no cell surface proteins (CSPs) have been identified from Alexandrium, and this lack of characterization has impeded our understanding of Alexandrium.

A number of proteins and enzymes reside on the cell surface and outer membrane of phytoplankton, such as high-affinity binding proteins [9-11], transporters [12-16], stress proteins [17,18], signaling proteins [19] and ectoenzymes [20-27]. These proteins play important roles in 
nutrient utilization, defense, signaling, cell adhesion, and cell recognition. The outmost membrane of the Alexandrium thecal wall is a subcellular component of substantial interest with regard to the various aspects of cell surface associated ecophysiology. However, there are few experimental data available concerning the outer membrane of Alexandrium, compared with those of other organisms, because of incomplete genome sequences of this genus. Thus far, only limited CSPs and enzymes have been identified and characterized at biochemical and functional levels, and the mechanisms of their functions and localization have not been elucidated [28-32]. Some studies indicate that CSPs and their activities are induced or increased by factors that limit the growth of these eukaryotic phytoplankton because of potentially enhanced cell scavenging of nutrients [28-30]. However, dinoflagellate CSPs may also have other important properties. For example, in Dictyostelium discoideum, CSPs have been reported to be involved in signaling pathways [19]. Evidently, CSPs present an important site of interaction between algal cells and their environment. Therefore, a better understanding of the structure and composition of the dinoflagellate cell surface may contribute to revealing important physiological activities on the cell surface and the mechanism that causes blooming of dinoflagellate species.

The study of CSPs has relied on various methods to isolate and identify CSPs from the cell surface or outmost membrane of dinoflagellates. A current strategy is labeling the CSPs of intact cells using vectorial labeling [31] or biotinylation [32] reagents prior to extraction. The major problem with these pre-labeling systems is the loss of protein solubility due to multiple additions of large hydrophobic groups to the proteins. Moreover, these methods can only address one or a few proteins at one time. Another strategy is isolation of CSPs by sequential extraction from whole cells. However, this approach not only extracts CSPs, but also other cell wall-associated proteins and results in potential cross contamination with cytosolic proteins [33]. Recent modifications of traditional DIGE procedures have enabled an elegant examination of CSPs by protein labeling prior to lysis $[34,35]$. This method has been used to label human cell lines in vitro and in vivo [34], bacterial CSPs [36] and the monocyte plasma membrane [37], and has been shown to be a powerful tool to study CSPs.

A. catenella DH01, a major HAB species that is widely spread in the coastal waters of China, not only produces PSTs, but also has formed extensive blooms in the East China Sea in recent years [38]. Thus, A. catenella DH01 has become an economic and public health concern, and losses in mariculture and the threat to human life due to PST exposure are increasingly documented. In this study, we developed a simple and rapid method to label $A$. catenella DH01 cells with the fluorescent cyanine dye Cy3, compared three extraction methods for CSPs and identified CSPs using MALDI-TOF-TOF mass spectrometry (MS) and database searching. The goals of this study were to establish an efficient and reliable detection and extraction method for CSPs from dinoflagellates, construct a two-dimensional CSP reference map of $A$. catenella and characterize putative proteins to provide a foundation for future investigation of the function and expression of CSPs in A. catenella.

\section{Materials and methods}

\subsection{Organism and culture conditions}

A. catenella DH01 was provided by the Culture Collection Center of Marine Bacteria and Algae of the State Key Laboratory of Marine Environmental Science, Xiamen University, China. A unialgal isolate was routinely maintained in $\mathrm{K}$ medium [39] at $20^{\circ} \mathrm{C}$ under a $14 \mathrm{~h}: 10 \mathrm{~h}$ light:dark photoperiod at a light intensity of approximately $100 \mu \mathrm{mol}$ photons $\mathrm{m}^{-2} \mathrm{~s}^{-1}$ provided by fluorescent lamps. Cells for surface labeling and CSP analysis were grown in $5 \mathrm{~L}$ flasks containing $4 \mathrm{~L} \mathrm{~K}$ medium under the culture conditions described above. $\mathrm{K}$ medium did not contain protein.

\subsection{Cell surface labeling}

The CSPs of $A$. catenella DH01 cells were labeled using the Ettan DIGE dyeing protocol with a minor modification. Algal cells $\left(1 \times 10^{7}\right)$ were collected by centrifugation at 800 $\times g$ for $5 \mathrm{~min}$ at $20^{\circ} \mathrm{C}$. The supernatant was removed, and the cell pellet was resuspended in $1 \mathrm{~mL}$ phosphate-buffered saline (PBS; $0.02 \mathrm{~mol} \mathrm{~L}^{-1}$ phosphate and $0.15 \mathrm{~mol} \mathrm{~L}^{-1} \mathrm{NaCl}$, $\mathrm{pH} 7.5$ ) and $1 \mathrm{~mL}$ ice-cold Hank's Balanced Salt Solution (HBSS; pH 8.5) successively, followed by centrifugation at $800 \times g$ at $4^{\circ} \mathrm{C}$ for $2 \mathrm{~min}$. The supernatant was removed, and the cell pellet was resuspended in $200 \mu \mathrm{L}$ ice-cold labeling buffer (HBSS, pH 8.5, and $1 \mathrm{~mol} \mathrm{~L}^{-1}$ urea). Intact cells were labeled with 600 pmol $\mathrm{Cy} 3$ for 20 min on ice in the dark. The reaction was stopped by adding $20 \mu \mathrm{L} 10 \mathrm{mmol} \mathrm{L}^{-1}$ lysine and incubating for $10 \mathrm{~min}$. Labeled cells were washed twice with $500 \mu \mathrm{L}$ HBSS ( $\mathrm{pH} 7.4$ ), followed by centrifugation at $800 \times g$ at $4^{\circ} \mathrm{C}$ for $2 \mathrm{~min}$. The fluorescence of intact Cy3-labeled algal cells was observed under a fluorescence microscope (Leica DM 4500 B, Germany) using Leica FW4000 software.

\subsection{Protein extraction}

Three methods of protein preparation were used to extract the Cy3-labeled CSPs of A. catenella DH01 [40-42].

(i) The urea/amidosulfobetaine-14 (ASB-14) extraction method. Pre-chilled urea/ASB-14 extraction buffer $(0.5$ $\mathrm{mL}$ ) containing $7 \mathrm{~mol} \mathrm{~L}^{-1}$ urea, $2 \mathrm{~mol} \mathrm{~L}^{-1}$ thiourea, $1 \%$ ASB-14 (w/v), 1\% DTT (w/v) and 2\% carrier ampholytes was added to the cell pellet. Then, the cell pellet was sonicated on ice. Cell debris was removed by centrifugation at $20000 \times g$ for $30 \mathrm{~min}$ at $4^{\circ} \mathrm{C}$, and then $0.5 \mathrm{~mL}$ pre-chilled $20 \%$ trichloracetic acid (TCA)/acetone (w/v) was added to 
the supernatant followed by incubation for $30 \mathrm{~min}$ at $-20^{\circ} \mathrm{C}$ to precipitate proteins. The solution was then centrifuged at $20000 \times g$ for $30 \mathrm{~min}$ at $4^{\circ} \mathrm{C}$, and the supernatant was removed. The cell pellet was washed three times with ice-cold acetone containing $20 \mathrm{mmol} \mathrm{L}^{-1}$ DTT by centrifugation at $20000 \times g$ for $30 \mathrm{~min}$ at $4^{\circ} \mathrm{C}$ each time. Residual acetone was removed in a speed Vac, and proteins were dissolved in 50 $\mu \mathrm{L}$ rehydration buffer containing $7 \mathrm{~mol} \mathrm{~L}^{-1}$ urea, $2 \mathrm{~mol} \mathrm{~L}^{-1}$ thiourea, $1 \%$ ASB-14 (w/v), $2 \mathrm{mmol} \mathrm{L}^{-1}$ tributylphosphine (TBP) (w/v), 0.5\% immobilized $\mathrm{pH}$ gradient (IPG) buffer and a trace amount of bromophenol blue.

(ii) The $\mathrm{CaCl}_{2}-\mathrm{LiCl}$ sequential extraction method. The cell pellet was extracted twice with $2 \mathrm{~mL} \mathrm{CaCl}_{2}$ solution (5 mmol L ${ }^{-1}$ acetate buffer, $\mathrm{pH} 4.6$, and $0.2 \mathrm{~mol} \mathrm{~L}^{-1} \mathrm{CaCl}_{2}$ ), followed by two extractions with $2 \mathrm{~mL} \mathrm{LiCl}$ solution $(5$

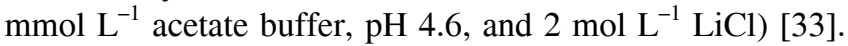
Protein precipitation was performed as described above. Proteins were dissolved in $50 \mu \mathrm{L}$ rehydration buffer containing $7 \mathrm{~mol} \mathrm{~L}^{-1}$ urea, $2 \mathrm{~mol} \mathrm{~L}^{-1}$ thiourea, $4 \%$ CHAPS, 65 $\mathrm{mmol} \mathrm{L}^{-1}$ DTT (w/v) and $0.5 \%$ IPG buffer.

(iii) The Trizol extraction method. Trizol reagent (1 $\mathrm{mL}$ ) was added to the cell pellet, followed by sonication on ice. Then, $200 \mu \mathrm{L}$ chloroform was added to the cell lysate before shaking vigorously for $15 \mathrm{~s}$. The mixture was allowed to stand for $5 \mathrm{~min}$ at room temperature before centrifugation at $12000 \times g$ for $15 \mathrm{~min}$ at $4^{\circ} \mathrm{C}$. The top pale-yellow to colorless layer was removed, $300 \mu \mathrm{L}$ ethanol was added to resuspend the reddish bottom layer, and the mixture was centrifuged at $2000 \times g$ for $5 \mathrm{~min}$ at $4^{\circ} \mathrm{C}$. The supernatant was transferred to a new tube and $2 \mathrm{~mL}$ isopropanol was added. Then, the mixture was stored at $-20^{\circ} \mathrm{C}$ for at least $1 \mathrm{~h}$ to precipitate proteins. The mixture was then centrifuged at $14000 \times g$ for $30 \mathrm{~min}$ at $4^{\circ} \mathrm{C}$, and the recovered pellet was briefly washed with $95 \%$ ethanol and then air dried. Fifty microliters of rehydration buffer $\left(7 \mathrm{~mol} \mathrm{~L}^{-1}\right.$ urea, $2 \mathrm{~mol} \mathrm{~L}^{-1}$ thiourea, $4 \%$ CHAPS, $65 \mathrm{mmol} \mathrm{L}{ }^{-1}$ DTT (w/v) and $0.5 \%$ IPG buffer) was added to dissolve proteins.

For the three extractions described above, protein quantification was performed using a 2D Quant kit (GE Healthcare, Piscataway, NJ).

\subsection{Two-dimensional gel electrophoresis (2-DE) analysis}

Rehydration, isoelectric focusing (IEF) and equilibration were performed as described elsewhere [40]. Briefly, protein $(400 \mu \mathrm{g})$ obtained from dye-labeled A. catenella DH01 cells was subjected to IEF using an IPGphor III system (Amersham Biosciences, Xiamen, China) with $24 \mathrm{~cm}$ IPG strips (Immobiline Drystrip ${ }^{\mathrm{TM}}$, $\mathrm{pH} 3-10$ and 4-7; Amersham Biosciences) and then resolved on a $12.5 \%$ slab gel with sodium dodecylsulfate polyacrylamide gel electrophoresis. The gel was overlaid with $0.5 \%$ agarose (dissolved in running buffer containing bromophenol blue) and 2-DE was run using an Ettan DALTsix Vertical System (GE Healthcare, USA) at $1 \mathrm{~W} / \mathrm{gel}$ for $30 \mathrm{~min}$, and then at 15
W/gel until the dye front reached the bottom of the gel.

\subsection{Protein visualization}

After 2-DE, gels were scanned for Cy3-labeled proteins using a Typhoon ${ }^{\mathrm{TM}} 9400$ Imager (GE Healthcare) at a resolution of 100 pixels and an excitation wavelength of $532 \mathrm{~nm}$. Total proteins were visualized by staining gels with SYPRO Ruby (Molecular Probes ${ }^{\mathrm{TM}}$, Invitrogen, USA), following the standard protocol, and then scanned. After scanning, proteins were visualized using silver staining according to the method by Wang et al. [41].

\subsection{MS analysis}

CSP spots were manually excised from silver stained 2-DE gels, and then gel pieces were destained for 5 min with 200 $\mu \mathrm{L}$ destaining solution $\left(15 \mathrm{mmol} \mathrm{L}^{-1} \mathrm{FeK}_{3}(\mathrm{CN})_{6}\right.$ and 50 $\mathrm{mmol} \mathrm{L} \mathrm{Na}_{2} \mathrm{~S}_{2} \mathrm{O}_{3}$ ). After removing the destaining solution, gel pieces were washed three times with $800 \mu \mathrm{L}$ water and vortexed for $10 \mathrm{~min}$ each time at $50^{\circ} \mathrm{C}$. Acetonitrile $(200 \mu \mathrm{L})$ was added to the mixture, followed by incubation at room temperature with occasional vortexing until gel pieces became white and shrunken, and then the acetonitrile was removed. Trypsin buffer (typically, $5 \mathrm{ng} \mu \mathrm{L}^{-1}$ Promega Sequencing Grade Modified Trypsin in $10 \mathrm{mmol} \mathrm{L}^{-1}$ $\mathrm{NH}_{4} \mathrm{HCO}_{3}$ ) was added, depending on the quantities of protein loaded for 2-DE, to cover the dry gel pieces that were then placed in an ice bucket or fridge. After saturation for 30 min and when the gel pieces were completely rehydrated, the trypsin was removed. Next, $10-15 \mu \mathrm{L} 10 \mathrm{mmol} \mathrm{L}^{-1}$ ammonium bicarbonate buffer was added to cover the gel pieces for enzymatic cleavage. Tubes containing the gel pieces were then placed into an air circulation incubator at $37^{\circ} \mathrm{C}$ for $4-16 \mathrm{~h}$.

After gel digestion, $1.4 \mu \mathrm{L}$ peptide solution was mixed with $0.4 \mu \mathrm{L}$ matrix (4-hydroxy- $\alpha$-cyanocinnamic acid) in $30 \%$ acetonitrile (CAN) and $0.1 \%$ trifluoroacetic acid (TFA) before spotting onto the target plate. MALDI-TOF and tandem TOF/TOF MS were then carried out using an $\mathrm{AB}$ SCIEX MALDI TOF-TOFTM 5800 Analyzer (AB SCIEX, Shanghai, China). Peptide mass maps were acquired in positive reflection mode, averaging 1000 laser shots per MALDI-TOF spectrum and 2000 shots per TOF/TOF spectrum (the resolution was 20000). Calibration mixtures (Applied Biosystems) were used to calibrate the spectrum to a mass tolerance within 0.1 Da. Parent mass peaks with a mass range of $800-4000 \mathrm{Da}$ and a minimum signal to noise ratio of 50 were chosen for tandem TOF/TOF analysis.

\subsection{Database search}

The contaminant $\mathrm{m} / \mathrm{z}$ peaks originating from human keratin, trypsin autodigestion or matrix were included in the exclusion list used to generate the peptide mass list used for 
database searching. Database searching used internal MASCOT (Version 2.2, Matrix Science, London, UK) software to match MS and MS/MS data against NCBInr databases (updated December, 2010, containing 4607655 entries) without taxonomic restriction. Searches were conducted using the following setting: one missed cleavage, $P$ $<0.05$ significance threshold, $50 \mathrm{ppm}$ peptide mass tolerance, $0.25 \mathrm{Da}$ fragment mass tolerance, $50 \mathrm{ppm}$ peptide mass tolerance, 0.1 Da MS/MS ion tolerance, carbamidomethylation of cysteine as a fixed modification, and methionine oxidation as a variable modification. Once the confident identifications were removed after searching against the NCBInr database, the rest was searched against the dinoflagellate expressed sequence tag (EST) database (downloaded from NCBI, updated December, 2010, containing 171550 entries). Protein identification, performed using MASCOT software, was considered to be correct at a $>95 \%$ confidence interval for the protein score, and hits were considered to be significant when the total ion confidence interval (C.I., \%) was $\geqslant 95$ and the $E$-value was below $\mathrm{e}^{-20}$ or less for EST search results.

\section{Results and discussion}

\subsection{Surface labeling of $A$. catenella DH01 cells}

The principle of CyDye surface labeling is based on the chemistry of minimal labeling CyDyes to covalently bind the $\varepsilon$-amine of lysine with their $N$-hydroxysulfosuccinimide ester group via an amide linkage. Impermeability of the amphiesma of A. catenella to fluorescent dyes is a crucial requirement for selective labeling of CSPs. Thus, in this study, both amphiesma permeability and active uptake of CyDye fluorophores by cells were conducted in suspension. About $1 \times 10^{7}$ viable A. catenella cells were labeled with $\mathrm{Cy} 3$. After labeling, excess dye was removed and cells were observed under fluorescence microscopy. Cy3-labeled cells were red with a ring-shaped membranous staining pattern (Figure 1). Such fluorescent images of Cy3-labeled cells indicated that these cells remained intact and their CSPs were labeled with Cy3.

Several cell surface labeling methods, such as isotope vectorial labeling [31] and biotinylation labeling [32], have been developed to investigate the CSPs of dinoflagellates. However, these methods lead to loss of CSP solubility due to the complex procedure involved in labeling intact cells. Moreover, these methods can only address one or a few proteins at one time. Fluorescent labeling of CSPs with Ettan DIGE dyes is a newly developed method and has been widely applied to study the CSPs of various human cell lines [34], bacteria [36] and the monocyte plasma membrane [37]. The results demonstrate that CyDyes can specifically bind to CSPs, with minimal labeling of cytosolic proteins because CyDyes cannot penetrate the outmost membrane of living cells [43-47]. Moreover, labeling is

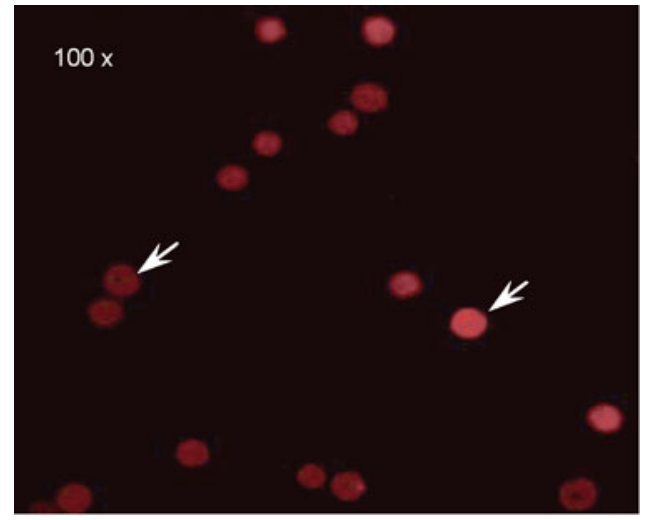

Figure 1 Surface labeling of living cells. Cy3-labeled algal cells were examined using a fluorescence microscope with the excitation wavelength of Cy3. Images show how Cy3 selectively labels the CSPs of live cells, a ring-shaped staining pattern (marked by arrows) and that the staining procedure does not compromise the integrity of the cell wall.

performed under mild conditions (HBSS, $\mathrm{pH}$ 8.5) that are less likely to alter the structure of the algal cell surface [36]. Importantly, cyanine dyes are small and do not alter protein migration in gels [48]. The present study used Cy3 to label the CSPs of A. catenella DH01 by a similar method used for labeling human cell lines [34]. This method was simple compared with other methods to detect algal CSPs (e.g. biotinylation), and did not require specific treatment or designated facilities to perform, as is the case using radioactive materials to label proteins.

\subsection{CSP extraction}

The 2-DE profiles of A. catenella DH01 CSPs prepared using three extraction methods are shown in Figure 2. Among them, the Trizol method obtained the optimal result with regard to protein spot number and resolution, and 41 CSP spots were identified by 2-DE (Figure 2(c)). The majority of proteins were separated in the molecular mass range of $20-98 \mathrm{kD}$ and had an isoelectric point range of 4.5-7.0. The urea/ASB-14 extraction with TCA/acetone precipitation method (Figure 2(a)) also yielded 34 CSPs spots, while the $\mathrm{CaCl}_{2} / \mathrm{LiCl}$ extraction method yielded just 12 CSPs (Figure 2(b)).

The 2-DE patterns, stained using SYPRO Ruby (Figure 3(b)) and silver staining (Figure 3(c)), were also determined in this study. Cy3-labeled proteins (Figure 3(a) and (b)) could be accurately aligned and silver stained spots corresponding to SYPRO Ruby and Cy3-labeled CSPs were easily discerned. The results suggested that we selectively targeted proteins by fluorescent labeling of algal cells to identify CSPs using MALDI TOF/TOF MS analysis.

\subsection{Protein identification}

Thirty-eight protein spots were visualized using fluorescence scanning and silver staining, which were excised 

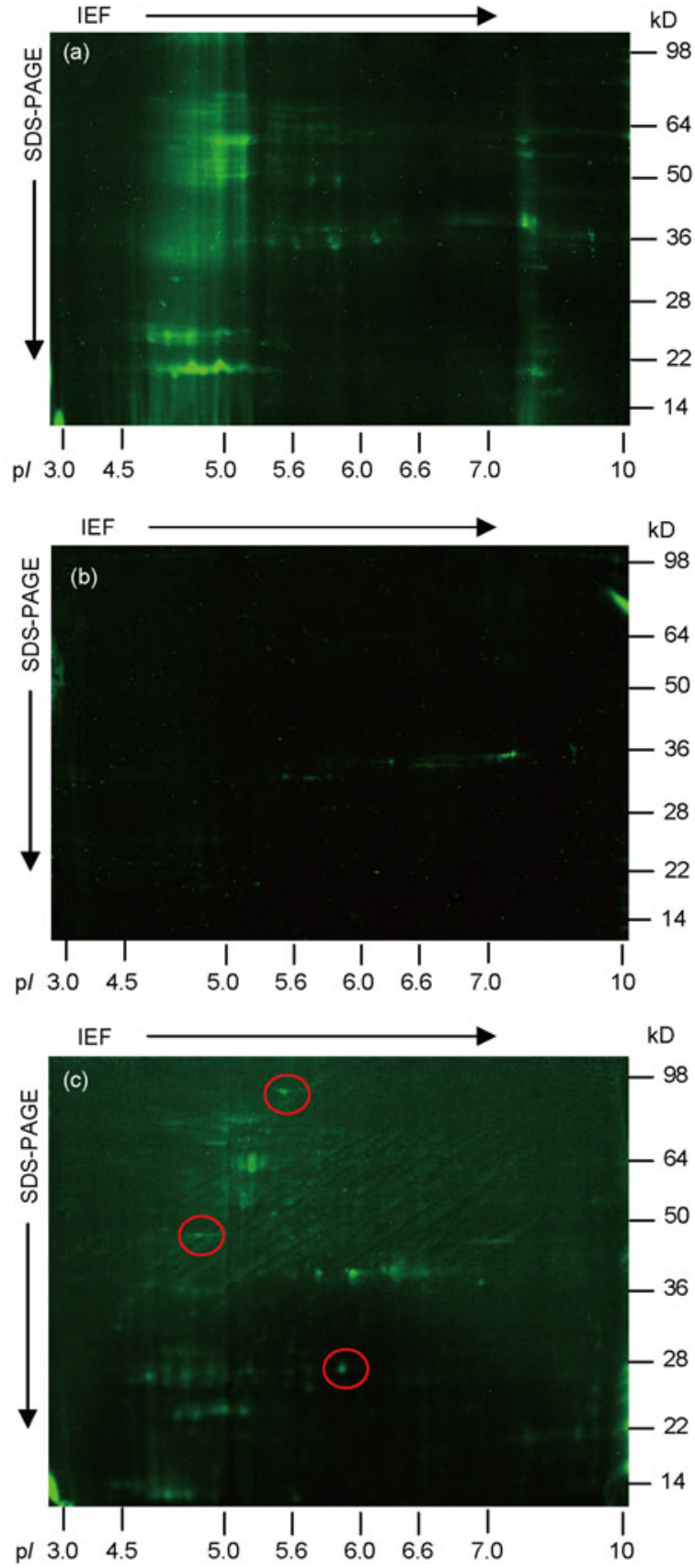

Figure 2 2-DE protein profiles of CSPs extracted using three methods (pH 3-10). (a) Urea/ASB-14 extraction; (b) $\mathrm{CaCl}_{2} / \mathrm{LiCl}$ sequential extraction; (c) Trizol extraction. Protein spots in the circular regions in (c) show unique proteins on the 2-DE gel obtained using Trizol extraction, compared with that of the other two methods.

from silver stained gels (Figure 3(c)) and trypsinized prior to MALDI TOF/TOF MS analysis. The nine confident identifications of Cy3-labeled CSPs searched against the NCBInr database are shown in Table 1, and the five EST search results are listed in Table 2 . The remaining 24 protein spots could not be positively identified as protein orthologs in the protein database and were assigned as unknown or novel proteins.

MS analysis of the CSPs of A. catenella DH01 led to

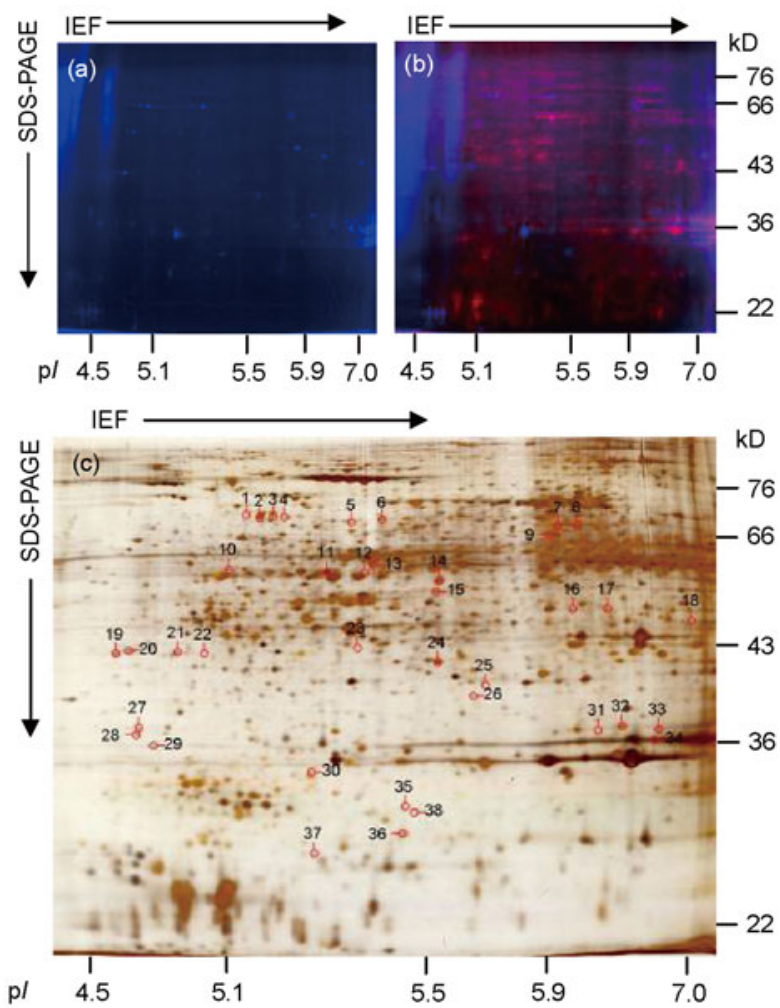

Figure 3 Fluorescence and silver stained 2-DE pattern of proteins extracted from the Cy3-labeled cells of A. catenella using the Trizol method. Proteins were resolved on non-linear, $\mathrm{pH}$ 4-7 IPG strips in the first dimension followed by separation on precast polyacrylamide gels $(12.5 \%)$ in the second dimension. (a) A typical 2-D pattern of the CSPs of Cy3-labeled Alexandrium cells; (b) two-color image of 2-D-separated CSPs (blue) and total proteins (red) labeled with Cy3 and SYPRO Ruby, respectively; (c) the corresponding silver stained image. Spots marked with a number were subjected to MALDI TOF/TOF analysis.

identification of two proteins with chaperone functions, namely heat shock protein (HSP) 70C (spot 2) and HSP70 (spot 3). Cell surface localization of chaperones has been reported in several studies [49-51]. HSP70, previously characterized as a chaperone, regulates apoptosis in response to heat shock and oxidative stress by preventing the release of cathepsins and cytochrome $c$ [52]. This protein prevents lysosome-mediated sudden death by binding to lysosomal cathepsins B, D, L and $\mathrm{H}$ and providing structural stability to lysosomal membranes [37,53]. It is unclear how the localization of these HSPs is targeted to the cell surface, but it is unlikely to be the classic secretory pathway (endoplasmic reticulum (ER) to Golgi to plasma membrane). A previous study demonstrats that thioredoxin H-type 5 (spot 28) is secreted in a non-classic manner that is independent of the ER-Golgi pathway [51].

Spot 5 was identified as a homologue of the cell division protein FtsH that has an integral cytoplasmic membrane protein spanning the membrane twice and a large cytoplasmic carboxyterminal with a putative ATP-binding domain [54]. FtsH participates in the assembly of proteins into and through the membrane and is required for cells to ensure 

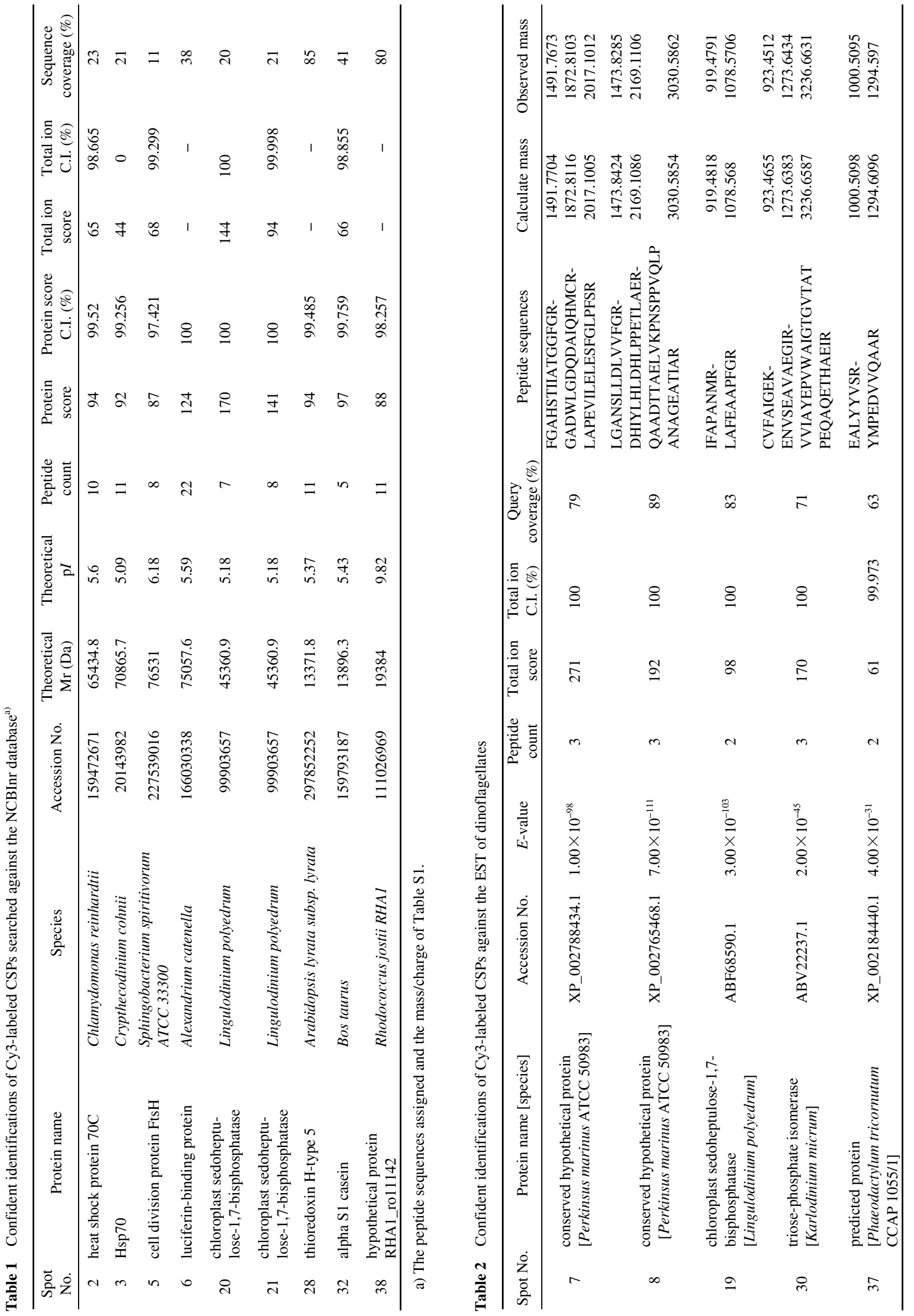
efficient stop-transfer of some transmembrane proteins [55]. Moreover, FtsH is significantly homologous to members of an ATPase family found in eukaryotic cells [56].

It should be noted that several intracellular proteins were identified in this study, such as luciferin-binding protein (spot 6) and chloroplast sedoheptulose-1,7-bisphosphatases (spots 19, 20 and 21). Presently, we have no explanation for these results. One possibility is that CSPs were contaminated by intracellular proteins during labeling, but no other intracellular high abundance proteins were found in this study. Moreover, all proteins identified in this study were low abundance proteins in silver stained gels. Therefore, we postulate that these proteins might be transmembrane proteins or channel proteins associated with the outermost membrane. It is known that the chloroplast of A. catenella has a radiating structure from the central pyrenoid complex to the cell wall, which contacts the plasma membrane [58]. In addition, cells organized as chains are interconnected by a cytoplasmic connection that passes through the so-called attachment pore of the pore plate and a pore in the posterior sulcal plate [57,58]. This connection between cells is prone to breakage by mechanical disturbance, and proteins located on or associated with the plasma membrane are released from the attachment pore and labeled with CyDye. Potential direct physical connections may occur between the plasma membrane and the cell wall and/or interactions at the plasma-cell wall interface [59]. In addition to the above proteins, a small number of proteins were identified as hypothetical proteins or functionally unknown proteins. This result was not surprising because the dinoflagellate genome has not been completely sequenced and few studies have been conducted on the CSPs of dinoflagellates.

In conclusion, this study developed a rapid and simple method for specific labeling and detection of the CSPs of $A$. catenella cells using CyDye DIGE fluor minimal dyes, which provides a potential tool for further proteomic studies of CSPs from Alexandrium and other dinoflagellate species. The fluorescent labeling used in this study does not interfere with subsequent identification of proteins excised from gels by MS because most peptides do not contain the label. Because cyanine dyes are compatible with 2-DE and MS, they can be used in proteomic approaches to identify dinoflagellate CSPs. More insights can be expected into the rapid analysis of many CSPs, as well as the characterization of the proteomic changes occurring at the cell surface in response to environmental stress, which will ease the identification of new surface-exposed targets that may improve our understanding of the relationship between cells and environmental variations.

This work was supported by the National Natural Science Foundation of China (40876059), the National Key Basic Research Program of China (2010CB428703), the Doctoral Fund of Ministry of Education of China (20070384014), the Excellent Group and the Program for New Century Excellent Talents in University to D.Z. Wang. We thank Prof. John Hodgkiss for his assistance with the English in this manuscript.
1 Anderson D M, Kulis D M, Doucette G J, et al. Biogeography of toxic dinoflagellates in the genus Alexandrium from the northeastern United States and Canada. Mar Biol, 1994, 120: 467-478

2 Yasumoto T, Van Dolah F M, Gestal-Otero J J, et al. Seafood and freshwater toxins: Pharmacology, physiology and detection. In: Botana L M, ed. Food Science and Technology. New York: Marcell Dekker, 2000. 1-18

3 Cembella A D. Ecophysiology and metabolism of paralytic shellfish toxins in marine microalgae. Physiol Ecol Harmful Algal Blooms, 1998, 41: 381-403

4 Hallegraeff G M. Harmful algal blooms: A global overview. In: Hallegraeff G M, Anderson D M, Cembella A D, eds. Manual on Harmful Marine Microalgae. Paris: Imprimerie Landais, 2005. 25-49

5 Morrill L C, Loeblich A R. Cell division and reformation of the amphiesma in the pelliculate dinoflagellate, Heterocapsa niei. J Marine Biol Assoc UK, 1984, 64: 939-953

6 Loeblich A R III, Loeblich L A. Dinoflagellates: Structure of the amphiesma and re-analysis of thecal plate patterns. Hydrobiologia, 1985, 123: 177-179

7 Loeblich A R III. The amphiesma or dinoflagellate cell covering. Proc. North American Paleont. Convention, Lawrence, Kansas. Chicago. Lawrence: Allen Press, 1969. 867-929

8 Pfiester L, Anderson D, Taylor F. The Biology of Dinoflagellates. London: Oxford, 1987

9 Scanlan D J, Mann N H, Carr N G. The response of the picoplanktonic marine cyanobacterium Synechococcus species WH7803 to phosphate starvation involves a protein homologous to the periplasmic phosphate-binding protein of Escherichia coli. Mol Microbiol, 1993, 10: 181-191

10 Song B, Ward B B. Molecular cloning and characterization of high-affinity nitrate transporters in marine phytoplankton. J Phycol, 2007, 43: 542-552

11 Chung C C, Hwang S P, Chang J. Identification of a high-affinity phosphate transporter gene in a prasinophyte alga, Tetraselmis chui, and its expression under nutrient limitation. Appl Environ Microbiol, 2003, 69: 754-759

12 ElBerry H M, Majumdar M L, Cunningham T S, et al. Regulation of the urea active transporter gene (DUR3) in Saccharomyces cerevisiae. J Bacteriol, 1993, 175: 4688-4698

13 Tamai Y, Toh-e A, Oshima Y. Regulation of inorganic phosphate transport systems in Saccharomyces cerevisiae. J Bacteriol, 1985, 164: 964-968

14 Hildebrand M. Cloning and functional characterization of ammonium transporters from the marine diatom Cylindrotheca fusiformis (Bacillariophyceae). J Phycol, 2005, 41: 105-113

15 Allen A E. Beyond sequence homology: Redundant ammonium transporters in a marine diatom are not functionally equivalent. J Phycol, 2005, 41: 4-6

16 Maldonado M T, Price N M. Reduction and transport of organically bound iron by Thalassiosira oceanica (Bacillariophyceae). J Phycol, 2001, 37: 298-310

17 Davis A K, Hildebrand M, Palenik B. A stress-induced protein associated with the girdle band region of the diatom Thalassiosira pseudonana (Bacillariophyta). J Phycol, 2005, 41: 577-589

18 Landry D M, Gaasterland T, Palenik B P. Molecular characterization of a phosphate-regulated cell-surface protein from the coccolithophorid, Emiliania huxleyi (Prymnesiophyceae). J Phycol, 2006, 42: 814-821

19 West C M, Zhang P, McGlynn A C, et al. Outside-in signaling of cellulose synthesis by a spore coat protein in Dictyostelium. Eukary Cell, 2002, 1: 281-292

20 Palenik B, Morel F M M. Amino acid utilization by marine phytoplankton: A novel mechanism. Limnol Oceanogr, 1990: 260-269

21 Palenik B, Morel F M M. Comparison of cell-surface $L$-amino acid oxidases from several marine phytoplankton. Mar Ecol Prog Ser, 1990, 59: 195-201

22 Palenik B, Morel F M M. Amine oxidases of marine phytoplankton. Appl Environ Microbiol, 1991, 57: 2440-2443

23 Strojsova A, Vrba J, Nedoma J, et al. Extracellular phosphatase activity of freshwater phytoplankton exposed to different in situ phos- 
phorus concentrations. Mar Freshw Res, 2005, 56: 417-424

24 Middlemiss J K, Anderson A M, Stratilo C W, et al. Oxygen consumption associated with ferric reductase activity and iron uptake by iron-limited cells of Chlorella kessleri (Chlorophyceae). J Phycol, 2001, 37: 393-399

$25 \mathrm{Xu} \mathrm{Y,} \mathrm{Wahlund} \mathrm{T} \mathrm{M,} \mathrm{Feng} \mathrm{L,} \mathrm{et} \mathrm{al.} \mathrm{A} \mathrm{novel} \mathrm{alkaline} \mathrm{phosphatase} \mathrm{in}$ the coccolithophore Emiliania huxleyi (Prymnesiophyceae) and its regulation by phosphorus. J Phycol, 2006, 42: 835-844

26 Gau A E, Heindl A, Nodop A, et al. $L$-amino acid oxidases with specificity for basic $L$-amino acids in Cyanobacteria. Zeitschrift Fur Naturforschung C, 2007, 62: 273-284

27 Dyhrman S T, Palenik B. Characterization of ectoenzyme activity and phosphate-regulated proteins in the coccolithophorid Emiliania huxleyi. J Plankton Res, 2003, 25: 1215-1225

28 Dyhrman S T, Palenik B. The identification and purification of a cell-surface alkaline phosphatase from the dinoflagellate Prorocentrum minimum (Dinophyceae). J Phycol, 1997, 33: 602-612

29 Stoecker D K, Gustafson D E. Cell-surface proteolytic activity of photosynthetic dinoflagellates. Aquat Microb Ecol, 2003, 30: 175-183

30 Dyhrman S T. Ectoenzymes in Prorocentrum minimum. Harmful Algae, 2005, 4: 619-627

31 Bertomeu T, Hastings J W, Morse D. Vectorial labeling of dinoflagellate cell surface proteins. J Phycol, 2003, 39: 1254-1260

32 Palenik B, Koke J A. Characterization of a nitrogen-regulated protein identified by cell surface biotinylation of a marine phytoplankton. Appl Environ Microbiol, 1995, 61: 3311-3315

33 Robertson D, Mitchell G P, Gilroy J S, et al. Differential extraction and protein sequencing reveals major differences in patterns of primary cell wall proteins from plants. J Biol Chem, 1997, 272: 15841-15848

34 Mayrhofer C, Krieger S, Allmaier G, et al. DIGE compatible labelling of surface proteins on vital cells in vitro and in vivo. Proteomics, 2006, 6: 579-585

35 McNamara L, Dalby M, Riehle M, et al. Fluorescence two-dimensional difference gel electrophoresis for biomaterial applications. J Roy Soc Interface, 2010, 7(Suppl 1): S107-S118

36 Anaya C, Church N, Lewis J. Detection and identification of bacterial cell surface proteins by fluorescent labeling. Proteomics, 2007, 7: 215-219

37 Kadiu I, Wang T, Schlautman J, et al. HIV-1 transforms the monocyte plasma membrane proteome. Cell Immunol, 2009, 258: 44-58

38 Wang D Z, Zhang S G, Gu H F, et al. Paralytic shellfish toxin profiles and toxin variability of the genus Alexandrium (Dinophyceae) isolated from the Southeast China Sea. Toxicon, 2006, 48: 138-151

39 Keller M D, Selvin R C, Claus W, et al. Media for the culture of oceanic ultraphytoplankton. J Phycol, 1987, 23: 633-638

40 Wang D Z, Lin L, Chan L L, et al. Comparative studies of four protein preparation methods for proteomic study of the dinoflagellate Alexandrium sp. using two-dimensional electrophoresis. Harm Algae, 2009, 8: 685-691

41 Feiz L, Irshad M, Pont-Lezica R, et al. Evaluation of cell wall preparations for proteomics: A new procedure for purifying cell walls from Arabidopsis hypocotyls. Plant Methods, 2006, 2: 1-13
42 Lee F, Lo S. The use of Trizol reagent (phenol/guanidine isothiocyanate) for producing high quality two-dimensional gel electrophoretograms (2-DE) of dinoflagellates. J Microbiol Methods, 2008, 73: 26-32

43 Sidibe A, Yin X, Tarelli E, et al. Integrated membrane protein analysis of mature and embryonic stem cell-derived smooth muscle cells using a novel combination of CyDye/biotin labeling. Mol Cell Proteom, 2007, 6: 1788-1797

44 Alfonso P, Canamero M, Fernandez-Carbonie F, et al. Proteome analysis of membrane fractions in colorectal carcinomas by using 2D-DIGE saturation labeling. J Proteom Res, 2008, 7: 4247-4255

45 Khemiri A, Galland A, Vaudry D, et al. Outer-membrane proteomic maps and surface-exposed proteins of Legionella pneumophila using cellular fractionation and fluorescent labelling. Anal Bioanalyt Chem, 2008, 390: 1861-1871

46 Filatov A, Krotov G, Zgoda V, et al. Fluorescent immunoprecipitation analysis of cell surface proteins: A methodology compatible with mass-spectrometry. J Immunol Methods, 2007, 319: 21-33

47 Hagner-McWhirter A, Winkvist M, Bourin S, et al. Selective labelling of cell-surface proteins using CyDye DIGE fluor minimal dyes. J Vis Exp, 2008, (21), doi: 10.379/945

48 Lilley K, Friedman D. All about DIGE: Quantification technology for differential-display 2D-gel proteomics. Expert Rev Proteom, 2004, 1: 401-409

49 Kornilovs'ka I, Nilsson I, Utt M, et al. Immunogenic proteins of $\mathrm{Hel}$ icobacter pullorum, Helicobacter bilis and Helicobacter hepaticus identified by two-dimensional gel electrophoresis and immunoblotting. Proteomics, 2002, 2: 775-783

50 Jang J, Hanash S. Profiling of the cell surface proteome. Proteomics, 2003, 3: 1947-1954

51 Shin B, Wang H, Yim A, et al. Global profiling of the cell surface proteome of cancer cells uncovers an abundance of proteins with chaperone function. J Biol Chem, 2003, 278: 7607-7616

52 Bivik C, Rosdahl I, llinger K. Hsp70 protects against UVB induced apoptosis by preventing release of cathepsins and cytochrome $c$ in human melanocytes. Carcinogenesis, 2006, 28: 537-544

53 Nylandsted J, Gyrd-Hansen M, Danielewicz A, et al. Heat shock protein 70 promotes cell survival by inhibiting lysosomal membrane permeabilization. J Exp Med, 2004, 200: 425-435

54 Tomoyasu T, Yamanaka K, Murata K, et al. Topology and subcellular localization of FtsH protein in Escherichia coli. J Bacteriol, 1993, 175: $1352-1357$

55 Akiyama Y, Ogura T, Ito K. Involvement of FtsH in protein assembly into and through the membrane. I. Mutations that reduce retention efficiency of a cytoplasmic reporter. J Biol Chem, 1994, 269: 5218-5224

56 Akiyama Y, Shirai Y, Ito K. Involvement of FtsH in protein assembly into and through the membrane. II. Dominant mutations affecting FtsH functions. J Biol Chem, 1994, 269: 5225-5229

57 Hansen G, Moestrup Ø. Fine-structural characterization of Alexandrium catenella (Dinophyceae) with special emphasis on the flagellar apparatus. Eur J Phycol, 1998, 33: 281-291

58 Kohorn B D. Plasma membrane-cell wall contacts. Plant Physiol, 2000, 124: 31-38

Open Access This article is distributed under the terms of the Creative Commons Attribution License which permits any use, distribution, and reproduction in any medium, provided the original author(s) and source are credited.

\section{Supporting Information}

Table S1 The mass/charge and peptide sequences of identified proteins

The supporting information is available online at csb.scichina.com and www.springerlink.com. The supporting materials are published as submitted, without typesetting or editing. The responsibility for scientific accuracy and content remains entirely with the authors. 